\title{
Sustainable Water Reallocation Planning for Semi- arid Parkland in Loess Plateau
}

\author{
A case study of tianshui town
}

\author{
Binyi Liu ${ }^{1 *}$ and Nan Wang ${ }^{2}$ \\ ${ }^{1}$ Doctor in landscape architecture. Professor, Dean of Landscape Architecture Discipline Committee in Department of Landscape \\ Architecture, College of Architecture and Urban Planning, Tongji University. ASLA. Department of Landscape Architecture, \\ College of Architecture and Urban Planning, Tongji University. 1239 Siping Road, Shanghai, 200092, P.R.C \\ ${ }^{2}$ Post-doc researcher in College of Environmental Science and Engineering, Tongji University. 1239 Siping Road, Shanghai, \\ 200092, P.R.C \\ *Corresponding author
}

\begin{abstract}
Rainwater catchment irrigation and municipal water supply are the current solutions for parkland water demand in townships of Loess Plateau. Rainwater catchment however, may lead to runoff imbalance or groundwater reduction, while the municipal water supply has priority for residential consumption and agricultural irrigation but not always for parkland. Thus, they are not favorable methods for parkland irrigation and may not guarantee parkland's water-consumption demand. Due to the reasons above, a new method of water supply adapted to the parkland in these semi-arid area townships should be proposed to decrease the pressure of rainwater catchment and municipal supply, and possibly reallocate available water resources. It should reduce the reliability of municipal supply and rainwater catchment for parkland water consumption, but utilize the drainage from residential area to aid the water demanding. Therefore, different reallocation plans can be made according to the factors such as evaporation, population, residential density, catchment capacity, parkland area, and vegetation in different towns. By utilizing green infrastructure and focusing on water reallocation through rainwater catchment and daily sewerage, multiple water reallocation plans can be adapted to the parkland and local habitats in townships in semi-arid area.
\end{abstract}

Keywords-water reallocation; landscape planning; recycled water; rainwater catchment; semi-arid area of Loess Plateau in China

\section{INTRODUCTION}

The semi-arid area of Loess Plateau in China, the place where the Chinese civilization originated, features profound cultural details. Thousands of years ago, this area was covered by forest and grasses, highlighted developed agriculture and the people lived and worked here in peace and contentment; nevertheless, with the capricious change of climates [1] and the increasing disturbance of human actions [2], the semi-arid area of Loess Plateau with small towns and villages as the priority have become lacked in water resources, rare vegetation, deserted farmland, poor living of residences and laggard economic conditions. The most outstanding problem lies in the shortage of water demanded by the vegetation growth, which further results in the gradual deterioration of human settlements [3][4].
At present, in small towns, the primary water recourses include rainwater and municipal water supply, in which, the municipal water supply is primarily to solve the resident's living demanding and the agricultural irrigation while the parkland in such small towns is irrigated by natural precipitation. The shortage of natural precipitation usually results in the impossibility of guaranteeing the vegetation's normal growth; nevertheless, such parkland is the important ecological space and leisure location of people in such small towns. As the municipal water supply cannot solve the landscape irrigation in priority, in combination of the regional characteristics, the irrigation methods primarily adopted at present involve the site catchment, the water collection by the catchment basin and the water storage with water cellar, etc.[5]; however, these methods have not definitely identified the relationship between the water and the vegetation, as a result, many problems such as excessive rainwater interceptive flow, reduction of the groundwater, shortage of water resources at lower-reaches and unbalanced capacity distribution of water catchment facilities [6] occur. In addition, as the town parkland is more related to the people's life while compared with the ecological parkland, the habitation advantage of towns should be more taken into consideration [7]; at meanwhile, efforts should be made to give play to the effect of human behaviors and living methods, etc. on the relationship between water sources and water demanded by the parkland.

\section{LANDSCAPE PLANNING METHOD OF WATER REALLOCATION}

As the residents at towns may produce domestic water, which is usually drained by the sewage pipes upon the municipal supply and utilization, but it has not been completely utilized; therefore, such water can be treated as the grey water for recycling use so as to supply it to the parkland within the town together with the rainwater irrigation and rainwater catchment upon reallocation and calculation.

As to the general thought of water reallocation, while the parkland is irrigated by natural rainfall, the rainwater is collected by such water catchment site and water cellar, etc. as roof and road surface, etc.; at meanwhile, the sewage and 
waste water from the resident's domestic water supplied by municipal facilities will be treated by decontamination and circulation for the sake of the town parkland. On this basis, several quantitative reallocation projects are presented as follows:

\section{A. Methods and Steps of Water Reallocation plAnning}

1) Determine the parkland area by incorporating the master plan of Tianshui Town;

2) Estimate the water demand of parkland in such an area by incorporating the local vegetation survey;

3) Judge if rainwater itself can meet the water demand of parkland in such area with information of local precipitation; normally extra water supply is needed in the semi-arid area, so extra water supply is calculated;

4) Calculate the amount of rainwater that can be collected via the surfaces other than the parkland by incorporating the quantity, capacity and location of the green infrastructure;

5) Calculate the amount of possible recycled daily sewage from residential area.

6) According to the figures above and other relevant information, quantize different combination projects of natural rainwater, rainwater catchment and recycled grey water so as to adopt proper planning method adaptable to the town characteristics.

\section{B. Calculation Method of Parkland Water Consumption,} Rainwater Quantity and Theoretical Guaranteed Parkland Area within the Town

1) Calculation of the parkland water consumption within the town

The parkland water consumption within the town can be expressed by the following formula:

$$
\begin{gathered}
\mathrm{N}=\mathrm{Agm} \times \mathrm{NP} \times \alpha \\
\mathrm{Agm}=(\mathrm{Ag} 1+\mathrm{Ag} 2+\mathrm{Ag} 3+\mathrm{Ag} 4) / \mathrm{NP}
\end{gathered}
$$

That is: (the parkland area + the accessory parkland area)/the population

In which, $\mathrm{N}$ refers to the water demanded by the parkland irrigation, Agm refers to the parkland area per person, Ag1 refers to garden parkland area, Ag2 refers to the production parkland area, Ag3 refers to the green buffer, Ag4 refers to the accessory parkland, NP refers to the urban population and $\alpha$ refers to the water demanded by the unit parkland.

2) Calculation of the irrigable water resources

(1) Calculation of usable grey water

$$
\mathrm{W}=\mathrm{L} \times \mathrm{NP} \times \beta
$$

$$
\mathrm{L}=\mathrm{L} 1+\mathrm{L} 2
$$

In which, NP refers to the urban population, $\mathrm{L}$ refers to the urban water consumption per person (excluding the water consumption that cannot be recycled such as the water for firefighting), L1 refers to the urban domestic water per person, which generally is $85 \sim 140 \mathrm{~L}$ per person per day, L2 refers to the production water per person and $\beta$ refers to the grey water recovery rate.

(2) Calculation of collectable rainwater resource for use

$$
\mathrm{R}=\mathrm{P} \times(\mathrm{A} \times \gamma)
$$

In which, $\mathrm{P}$ refers to the annual rainfall, A refers to the area of various rainwater catchments and $\gamma$ refers to the rainwater catchment coefficient.

3) In theority, the guaranteed irrigation parkland area:

$$
\mathrm{AG}=(\mathrm{W}+\mathrm{R}) /(\mathrm{ET}-\mathrm{P})
$$

In which, ET refers to the water demanded by the vegetation growth and $\mathrm{P}$ refers to the annual rainfall. Usually, the vegetation cannot grow normally if the water demanded by its growth is higher than the annual rainfall; in this case, the gap should be supplemented and supported by the grey water and the rainwater as collected. AG refers to the supportable area in total. When AG is larger than the town parkland area, the water has surplus, which can be allocated to supplement other parkland belt; when AG is smaller than the town parkland area, the water is lacked. Other methods should be taken into consideration to gain water resources and guarantee the irrigation, or reduce the parkland area for the temporary moment to guarantee the balance.

\section{DEMONSTRATION OF PARKLAND WATER REALLOCATION PLANNING METHOD WITH TIANSHUI TOWN AS AN EXAMPLE}

Tianshui Town located at Huan County, Gansu Province, China is adopted as the demonstration example in respect of water reallocation planning method. As located at the representative semi-arid area of Loess Plateau, it features the temperate semi-arid climate, drought, little rain, high-coldness, strong wind and sand, barren earth and high evaporation with the annual rainfall of $350 \mathrm{~mm}$ on average. At present, the control area within the planned area at Tianshui Town is $342.23 \mathrm{hm}^{2}$. The planned construction area is $184.54 \mathrm{hm}^{2}$ in 2030 , located at the northern part of the town of $526 \mathrm{~km}^{2}$.

\section{A. Calculation of the Relationship between Usable Water and Water Demanded by the Parkland}

\section{1) Parkland area of tianshui town}

At present, the planned construction area is $184.54 \mathrm{hm}^{2}$ at Tianshui Town. Add the parkland area and the accessory parkland area of other various construction sites, $67.62 \mathrm{hm}^{2}$ in total. 


\section{2) Parkland water consumption within the town}

According to the vegetation survey at the town, native vegetation as Robinia Pseudoacacia L., Caragana Intermedia Intermedia, Hippophae Rhamnoides Linn and Astragalus Adsurgens Pall.are usually planted at local place. Upon measurement and calculation, the average water consumption of the parkland per $\mathrm{hm}^{2}$ is $5167 \mathrm{t} / \mathrm{hm}^{2} / \mathrm{y}$ or $516.7 \mathrm{~mm} / \mathrm{y}$ on avearge.

The total water consumption of parkland is: $67.62 \mathrm{hm}^{2} \times 5167 \mathrm{t} / \mathrm{hm}^{2} / \mathrm{y}=349,300 \mathrm{~m} 3 / \mathrm{y}$

3) Water supplied to virescence within the town due to shortage of rainfall

The annual rainfall in Tianshui Town is $350 \mathrm{~mm}$ on average. In order to guarantee the parkland's normal growth, the rainwater catchment or the recycled grey water from the town construction sites has to be adopted to supplement the water consumption.

Extra water catchment: $\left(5167 \mathrm{t} / \mathrm{hm}^{2} / \mathrm{y}-3500 \mathrm{t} / \mathrm{hm}^{2} / \mathrm{y}\right) \times 67.62$ $\mathrm{hm} 2 /=112,700 \mathrm{~m} 3 / \mathrm{y}$

4) Grey water resources arising from the town water supply

(1) Estimation of domestic sewage at the town

Acording to the general planning of Tianshui Town (20032020), water for production, living and fire fighting is supplied by the unified water supply system.

The domestic water consumption standard at the town: in the near future $50 \mathrm{~L} /($ person $\cdot d)$ and in the long future $70 \mathrm{~L} /($ person $\cdot \mathrm{d})$.

The comprehensive water consumption at the town: in the near future $100 \mathrm{~L} /($ person $\cdot d)$ and in the long future $150 \mathrm{~L} /($ person $\cdot \mathrm{d})$.

Proportion of the concentrative water supply in the total water consumption: in the near future $60 \%$ and in the long future $80 \%$.

The domestic sewage is calculated as per $75 \%$ of the total water consumption.

(2) Estimation of the grey water in the water catchment for parkland

The grey water recourses in the water catchment for parkland can be estimated in this way with the population as 12000 in 2030.

The domestic water consumption in total = $12000 \times 70 \mathrm{~L} / \mathrm{d}=840 \mathrm{~m} 3 / \mathrm{d}$

The domestic sewage in total $=840 \times 75 \%=630 \mathrm{~m} 3 / \mathrm{d}$

Adopt the domestic sewage recycling use coefficient $\alpha$ to get:

The domestic sewage for irrigation $=\alpha \times 630$ $\mathrm{m}^{3} / \mathrm{d}=\alpha \times 229950 \mathrm{~m}^{3} / \mathrm{y}$ (grey water arising from the town and the usable grey water), that is, $\alpha \times 230,000 \mathrm{~m}^{3} / \mathrm{y}$

\section{B. Reallocation of Rainwater Catchment and Grey Water Recourses within the Town}

According to the on-site survey, the current road surface, roof and yard areas in total are about $100,468.3 \mathrm{~m}^{2}$, and there are 292 water cellars with the water storage volume of $50 \mathrm{~m} 3$ ofeach cellar on average, $14,600 \mathrm{~m}^{3}$ in total; nevertheless, according to the general planning of the town, the water catchment efficiency on the concrete catchment surface is controlled between 55 and $86 \%$ with the highroad catchment efficiency above 63-85\%. In accordance with the local construction condition featuring the ration of $4: 1$ between the road surface, farmer's roof and the yard catchment surface area, the catchment efficiency of the minimum $63 \%$ and $55 \%$ should be adopted. In this sense, the water storage capacity of the catchment sites within the overall town can be promoted to $61746.8 \mathrm{~m}^{3}$ [8] annually, that is, $61,700 \mathrm{~m}^{3}$ water.

Project I: All the parkland water demand would be accomplished by rainwater catchment, then calculate the extra rainwater cistern volume or the catchment surface area, which can be calculated by $\mathrm{V}=112,700 \mathrm{~m}^{3}-61,700 \mathrm{~m}^{3}=51,000 \mathrm{~m}^{3}$.

Project II: No extra rainwater catchment infrastructure would be needed, by calculating and using the amount of grey water or recycled water from domestic sewage. In such consideration, the proportion of the catchment and the grey water is demanded. As to the grey water, transform and recycle the domestic sewage as per the proportion of $112,700 \mathrm{~m}^{3} / 230,000 \mathrm{~m}^{3}$, that is, adopt the recycling and utilization coefficient of $49.00 \%$. In this case, the parkland growth and irrigation within the town can be guaranteed under the condition of no rainwater catchment on a large scale.

Project III: Depend only on rainwater irrigation and recycled sewage and use no rainwater from the existing catchment cistern, then calculate the amount of grey water or recycled water transformed and recycled from domestic sewage according to the proportion of $51,000 \mathrm{~m}^{3} / 230,000 \mathrm{~m}^{3}$, that is, adopt the recycling and utilization coefficient of $22.17 \%$.

\section{CONCLUSION}

By utilizing green infrastructure and focusing on water reallocation through rainwater catchment and daily sewerage, multiple water reallocation plans can be adapted to the parkland and local habitats in townships in semi-arid area. Further studies can be focused on specific green infrastructure planning to quantify and locate the exact allocation of water resources.

\section{ACKNOWLEDGMENT}

This research project has been supported by National Nature Science Foundation of China (NSFC) under the subject 51178319 in $01 / 2012-12 / 2015$.

\section{REFERENCES}

[1] UNFCCC (2009). The 15th Conference of Parties (COP 15) of the United Nations Framework Convention on Climate Change).

[2] Liu, B-Y., Liu, H., Zhang, D-S., Dong, L-D., \& Wang N. (2013) Research Framework of Microclimate Responsive Design Theory and 
Method of Landscape Architecture in Urban Livable Environment in China. Proceedings of Council of Educators in Landscape Architecture.

[3] Wang, N., \& Liu, B-Y. (2010) A study on the Construction of New Type of Human Settlements in Arid Area of West China with the Guidance of "Trialism". 47th IFLA World Congress, Suzhou, PRC.

[4] Hershkovitz, L. (1993) Political Ecology and Environmental Management in the Loess Plateau, China. Human Ecology.

[5] Wiley, J., Hoboken S., \& Cahill, T. H. (2011) Low Impact Development and Sustainable Stormwater Management. New Jersey.
[6] Wang, N., \& Liu, B-Y. (2012) Regional Landscape Architecture Strategies in Multi-layers in Response to Rapid Urbanization in Arid Area of Loess Plateau. Proceedings of WRSA.

[7] Liu, B-Y. (1999) Trialism: The Philosophy of Human Settlements Science. Planners

[8] Lin, M. (2011) Planning and Design Mode and Technology of Green Infrastructure in Arid Area: A Case Study of Tianshui Town in Huan County, Gansu Province. Shanghai: Tongji 